\title{
State Legal Protection on Freedom of Religion: a Myth
}

\author{
Rini Fidiyani \\ Universitas Negeri Semarang \\ Gd. K1, Kampus UNNES Sekarang, Gunungpati, Semarang \\ fidiyani.rini@gmail.com
}

\begin{abstract}
The State does guarantee freedom of religion/belief in its constitution. However, the guarantee does not necessarily affect the people in practice. This research intended to analyze the freedom of religion/belief implementation in Indonesia. The approach method was normative and empirical. The results showed that the state does provide a legal instrument of freedom of religion/belief in its constitution, but the arrangement often found that the rule is contrary to the constitution. At the level of practice, violations of freedom of religion/belief are rampantly conducted by the state itself. In the records of religious observers, the state has become the main perpetrator in violations toward freedom of religion/ belief, and also the main supporter of non-state actors. If so, then the function of the state is no longer to protect citizens in implementing freedom of religion/belief, but as the main and first offender. This asserts that the state guarantees freedom of religion/belief as a myth. It is mandated by the constitution but not executed properly.
\end{abstract}

Keywords-Freedom of Religion/Belief; InterReligious Conflict; Tolerance; Legal Protection; Myths.

\section{INTRODUCTION}

We live with myths that limit our behavior. Courage or fear on something is determined by the myths built in society. Creation of myths emerges not without a purpose, even the rules in our life are usually explained by a mythical reason. The state in various ways portrays itself as a democratic, humanist, defensive and protective people. On the other hand, the state creates myths which justify or attempt to make the image which was really built on the myths. The state is the best myth-maker, and the best document in relation to myths is the constitution. The Constitution (and other legislation) is a collection of myths which will forever be a myth if the reality presented does not show the opposite.

One of the myths presented is related to freedom of religion and belief. Freedom of religion and belief is one of the rights that its existence and implementations are guaranteed by the constitution. Several provisions in the Constitution (Article 29 paragraph (2); Article 28E paragraph (1) and paragraph (2); Article 28I paragraph (1) and paragraph (2); Article 28J paragraph (1) and paragraph (2) of the 1945 Constitution), legislation (Article 4 and Article 22 paragraph (1) of Law Number 39 the Year 1999 on Human Rights state that these guarantees and some international provisions (such as the International Declaration of Human Rights and ICCPR) which have been ratified by Indonesia strengthen the guarantees of reedom of religion and belief.

In the study of relations between religion and state, Indonesia uses a substantive paradigm. In this category, the relationship between state and religion is symbiotic, a mutual relationship. According to this paradigm, the state needs ethical and moral guidance as taught by religion, whereas religion requires state guardianship for its sustainability and existence. In this context, Pancasila is a good example of this paradigm. This is in contrast to the secular paradigm that desires a strict separation between religion and state or the paradigm of a group that is formally conforming to fundamentalist ideals such as the doctrine of innal al-Islam al Din was al-Daulah (in fact Islam is religion and state) (Thohir, 2010: 167168)

The guarantees are given by the constitution, legislation, or international provisions as well as Indonesia's motto "Bhinneka Tunggal Ika" is indeed beautiful to hear and give a hope of a harmonious life. However, the reality is not beautiful as our imagination. Inter-religious conflicts are recorded everywhere, and not only that, it happens done by a principal actor which is the government. The government should guarantee the freedom. This is a paradox in the way Indonesian enforcing law or myths in the enforcement of the proven constitution (Fidiyani and Baidhowi, 2015; du Plessis, 2001).

Conflict as a sociological category contradicts the notions of peace and harmony, the latter being the result of the associative, while the first of the dissociative processes. The associative process is a unifying process and the dissociative process is that of divorcing or dividing. Conflict as a social fact involves at least two different religious parties, not as imaginary (conceptual) constructions but as historical facts that are still common today (Hendropus-pito 1983: 151). Conflict usually arises because of differences of interest or when there are conflicting (crash) encounters between two parties/groups due to competition or different interests. Universal interests (including security, happiness, physical worth, humanity, etc.), specific interests, independence, and priority, are volitional. (Pruitt and Rubin, 2004: 21)

Conflict is not defined or based on religion because basically all religions teach goodness. All religious believers believe in the truth of their 
religion, and consider other religious views to be false. This is the true root cause of the conflict (Pelly, 1999: Suparlan, 1999; 2000; Igadrie, 2002; Robinson, 2000). This view is called exclusivism (Misrawi, 2010: 176). Thus, the causal factor is not on religion (and its teachings) but on the understanding of religion by its adherents.

An effort to realize the state's mandate and goals should not be a place for those who violate the mandate. The state's treatment of citizens in the issue of freedom of religion and belief strengthens the myth. This paper will discuss country's efforts to build, strengthen, assess the myth and practice of freedom of religion and belief in Indonesia which can be said is an effort to institutionalize the myth. In the life as a nation, the presence of myth is necessary, especially in the abstract things, something that is not clear as good and bad; ambiguous things.

\section{METHOD}

This research was a qualitative research with normative and empirical law approach. The sources of the data in this study were human with his behavior, events, documents, archives and other objects. However, the main data sources in this study were words and actions, the rest was additional data such as documents and others. Data were collected by using an interactive and non-interactive method which were analyzed by using interactive analysis model.

\section{RESULTS}

\section{A. Country's Efforts to Build Myths of the Freedom} of Religion and Belief

Human's life and naturally the relationship among human is dominated by myth. Our attitude toward something is determined by myth which is within us. This myth will make us like or hate something. Therefore, the myth will cause us to have certain prejudices which against the myth. Only through our experiences, we can know the truth or the fault of the myth. The experience may be able to strengthen the myth, or it may also negate it (Junus, 1981).

Myth has not suddenly been born; it is built through a process of natural and artificial construction. Literary works, as well as other scientific works, may be a myth. However, the state is the best myth-maker, because it has full authority on behalf of its people. The state makes myths in the life of the nation for the citizens. This myth is even referred as a nation's great work. Unfortunately, the creation of this myth is not followed by its consistent manifestation; therefore, it results in some new myths. Myths can be an attraction which drones a person to sacrifice himself and his interests.

As the creator of a good myth, the state has created a myth regarding the issue of freedom of religion and belief which is easy listening and reading. The right to freedom of religion and belief (Kebebasan Beragama/Berkeyakinan $(K B B)$ ) is a right that cannot be reduced in any form (non derogable rights), in which this guarantee can be found in the constitution, national legislation, and international human rights instruments. Almost all countries regulate freedom of religion in their constitution (Nevitte and Cochrane, 2006; Smith, 2002; Blake, 2007; Ferarri, 2004; McCrudden, 2011; Parkinson, 2007)

In Indonesia, the regulation of KBB (specifically related to freedom of belief), is found in the Article 29 Paragraph (2) of the 1945 Constitution which stipulates that state guarantees the independence of every citizen to embrace his or her own religion and to worship according to his religion and belief. Then, this guarantee is assured by the Article 28 E Paragraph (2) and Article 28I Paragraph (2) of the 1945 Constitution resulting from the second amendment. This assurance is then reinforced by the Law Number 39 the Year 1999 on Human Rights Article 3 Paragraph (3), and Article 22 Paragraph (1) (Fidiyani, 2016; Carmella, 1991; Cumper, 1998).

Referring to the provisions of the ICCPR, the guarantee of the right to freedom of religion and belief is contained in Article 18 which provides a broader sense of religion, including beliefs. The scope of this right refers to the General Comment of the Human Rights Committee Number 22 which states that the right to thought, conscience, religion and belief (the definition of Article 18 including believers) in Article 18.1 is broad and deep; this right includes freedom of thought concerning all things, personal beliefs, and commitment to religion or belief, whether done individually or together (Fidiyani, 2016; Dickson, 1995).

There are two dimensions in the right to freedom of religion and belief which are individual and collective dimensions. Individual dimension is reflected in the protection of one's spiritual existence (internal forum), including choosing-substituting, adopting and embracing religion and belief. Collective dimension is reflected in the protection of one's existence to show their spiritual existence and defend it in public (external forum). The Article 18 of the ICCPR distinguishes a freedom of religion and belief and a freedom to manifest one's religion and belief. This distinction is legally very important to distinguish in which part a state is allowed to restrict and is prohibited to impose restrictions. The General Comment Number 22 also states that there is no religious or belief manifestation can be used as propaganda for war or advocacy of national, racial or religious hatred, which may lead to discrimination, hostility or violence (Nainggolan, et.al, 2009).

Although the rights to freedom of religion and belief are included in non-derogable rights, there are certain aspects which may be restricted. Article 28J of the 1945 Constitution and Article 18.3 of The ICCPR declare that the internal forum on this right shall not be restricted without exception, while the 
territory exercising or manifesting of the right to freedom of religion and belief (external forum) may be restricted. State restrictions and intervention are established in legislation as the norms which allow the public to participate in forming and overseeing its implementation, it is carried out by concerning the principles of necessity and proportionality (Nainggolan, et.al, 2009). From this condition, it seems that the efforts of the state in building myths are in accordance with international instruments. However, whether or not the effort is in line with the practice, it is interesting to be discussed by seeing the presented facts below.

\section{B. Affirmation of the Myth of the Freedom of Religion and Belief}

Myths can be rooted in society; however, there will always emerge of a new myth. Barthes in his book Mythologies explains the new myths in France especially those related to the myths created by advertisement. Nowadays, advertisements are not merely in the form of product offered by a corporation that appears through mass media and electronic. News which has uniform content from various media is a form of advertisement that can create a new myth. In a literary study, according to Junus (1981), myth is not formed through investigation, but through a rough-minded assumption which is generalized. Therefore, it more exists in society. It may live in gossip, and then it may be proven by concrete action. Myths may also be confronted with a work, so the work also forms myth.

A work may be a myth which may be in charge of establishing something (a myth of concern), but it may be in charge of remodeling something (a myth of freedom). Introduction with something will result in the new myth which is different from previous myth, or perhaps even against it. The myth will always be accompanied by another myth, which is a contradiction. This can be said to be a common trait in an open society which is in contrast to a closed society in which myth is absolute (Junus, 1981).

There are three categories of the implementation of the myth of freedom of religion and belief. First, it deals with an issue of building houses of worship; second, legal protection against believers; and thirdly, with regard to respect for differences (belief, sects, in one religion, and hate speech). All three become trigger factors as well as trigger the occurrence of conflict between religious communities. This paper will only describe some of those problems.

In general, the failure of a state to realize its constitutional duty in this issue raises the myths about freedom of religion and belief. The failure of the state is evident from the statistical data of The Wahid Institute (2014) which recorded incidents of violations of freedom of religion and belief in 2014, the total was 158 of incidents with 187 actions. Compared to 2013, the freedom of religion and belief violations in 2014 decreased by $42 \%$. In 2013, the number of violations was 245 incidents. This number also decreased $12 \%$ compared to 2012 . SETARA
Institute in 2015 recorded 196 incidents of freedom of religion and belief violations with 236 forms of action spreading across Indonesia. Compared to last year, this figure showed a significant increase. In 2014 , the number of violation incidents occurred was "only" 134 incidents, while the offended actions were "only" 177 actions. The increase in violations of freedom of religion and belief should be taken seriously by the stakeholders (Halili, 2016). Meanwhile, The National Commission on Human Right (2015) notes that the number of complaints of rights violations to freedom of religion and belief in 2015 was 87 complaints. This number increased compared to 2014 , which were only 74 complaints (average 6 complaints/month) (Fidiyani, 2016).

Based on the distribution of its territory, Wahid Institute, Setara Institute, and Komnas HAM, placed West Java as the highest place in violation of rights to freedom of religion and belief, followed by Jakarta, Aceh, East Java and Yogyakarta. In terms of actor actions, The Wahid Institute (2014) recorded $80(51 \%)$ incidents involving 98 (52\%) state actors; while 78 (49\%) incidents involving 89 (48\%) nonstate actors. Setara Institute noted that from 236 forms of violation of freedom of religion and belief, there are 98 state actions involving state organizers as actors in comparison to 138 acts committed by non-state actors. Compared with last year's data, the acts of violations committed by state actors have increased sharply from the previous which were "only" 39 actions turning to 98 actions in 2015. Cumulatively the percentage of action classification based on these actors do not undergo significantly from year to year. Society's groups are always the highest ranked actors of violations in against freedom of religion and belief (Halili, 2016). Komnas HAM (2015) actually recorded that almost $70 \%$ of freedom of religion and belief violations committed by the state (Fidiyani, 2016).

The National Commission on Human Rights in 2015 assessed Indonesia Ahmadiyah Jamaat (JAI) as the most numerous victims and Setara Institute actually listed the Shia as its biggest victim. They became the victim in 31 incidents. The five other groups who were the victims were a community, and Christians were the victims of 29 incidents and Muslims victims were in 24 incidents. The followers of the Beliefs were in 14 incidents, while $J A I$ was in 13 Incidents (Halili, 2016; Fidiyani, 2016).

Associated with the first issue (house of worship establishment), Setara Institute (2014) has ever assessed the enforcement of human right and its index to freedom of religion and belief. Generally, the index is 2.40. In the matter of freedom of house of worship establishment, the index is in 2.3 (from 17). The assessment from Setara Institute shows the issue of violation of freedom of religion and belief is very serious and needs special handling. The Wahid Institute (2014) recorded that the existence of actions which hampers/forbids or seals house of worship accounted of 17 cases and these are the most cases out of other violation for freedom of religion and belief. 
Taking a look at the doers or actors behind the violation of freedom of religion and belief, they are state and non-state, according to the research from Setara Institute (2016). It is noted that 16 cases are state's action (out of 98 cases) in the category of $K B B$ (violation of freedom of religion and belief) namely house of worship establishment. The actions include in the category are; worship restriction, the house of worship destruction, the house of worship revocation, and the house of worship establishment discontinuation. If we analyze further, the number could be more than what has been mentioned since discrimination or discriminatory policies also exist in a house of worship establishment. Actions taken by non-state actors in the same field according to Setara Institute are 33 cases (out of 138 cases), which includes worship/religious activities restriction, combustion, activities dismissal, the house of worship rejection and destruction.

The target of the offense in this context is the religious/faith group; therefore, automatically, the target of the offense act is the place of worship. In Setara Institute notes, throughout 2013, most cases lead to churches with 27 cases, 17 to mosques, 2 to monasteries, 2 to house of worship for certain belief and 1 to temple. Some places of worship that became the object of disturbance in violation of freedom of religion/belief in 2015 included churches, mosques, and houses of worship of certain beliefs. The worship house that got the highest disturbance was a place of Christian worship that were 15 churches, 9 mosques, and 2 houses of worship of certain beliefs. For 9 years (20017-2015), SETARA Institute (2016) recorded 331 houses of worship experienced disturbance with various actions such as combustion, destruction, failure of the establishment because of permission and others.

Komnas HAM (National Human Rights Commission) in 2015 noted that the act of banning, damaging or hampering the construction of houses of worship, whether churches, mosques or houses of worship were the most heavily charged action with 37 acts. The highest number of victims of these acts was Ahmadiyah Indonesia congregation (37 cases), Mosque and Mushala congregation (16 cases), Church Congregation (15 cases), individuals and community groups (10 cases each). The high number of victims from JAI indicates the issue of JAI is still not resolved by the central and regional governments. The existence of Joint Decree of the Ministry of Home Affairs, Ministry of Religious Affairs and Attorney General in 2008 on Ahmadiyah has not been able to answer various violations of Ahmadiyah people.

There is a correlation between the numbers of worship places destroyed and the number of victims (congregation). Violation of the freedom to build places of worship causes implication not only to the building of houses of worship but also to the congregation of the house of worship. The high number of victims of mosques and church congregations shows that the victims are not dominated by one religion alone, but are evenly distributed to almost all religions, depending on the majority-minority composition in one area which is often a factor in the violation of the right to $K B B$. These violations also indicate that the Joint Regulation of Ministry of Religious Affairs and the Ministry of Home Affairs Number 8 and Number 9 have not been fully effective in resolving the issue of places of worship.

Several independent institutions noted violations of KBB indicate that this issue is already an acute problem. Komnas HAM notes that there were six outstanding cases in 2015, [1] while the Setara Institute (2016) reported several prominent cases involving the rejection and destruction of houses of worship, inter-religious conflict, and intolerant acts.[2]

The depiction of the first case in Central Java can be seen from the following explanation. Social and Religious Study Institution (eLSA), a Community Study Institution ( $L S M)$ specialized in observing and examining $K B B$ in Central Java recorded several cases of $K B B$ violation. This article focuses on the issue associated with conflicts of the house of worship establishment. For the past three years of observation, eLSA noted several cases appeared to the public.[3]

Religious interests and religious believers in social life often overlap. This is where tensions and even conflicts in Indonesia often arise. Following Thohir's thought (2010: 167), then if the conflicts that occur across the stream in one religion - such as Sunni vs Syi'ah, Ahmadiyah, Indonesian Institute of Da'wah Islamiyah (Lembaga Dakwah Islamiyah Indonesia (LDII)) - a growing issue is a one-sided truth claim; if the categories of conflict are interreligious - such as Muslims with Christians - the issues that arise are the question of building houses of worship, the interests of power and so on. If the conflict is between religion and local belief, then the issue that develops is polytheism, religious deviation, and others, whereas if the conflict occurs between religion and religion, emerging issues are fundamentalism, extremism, and others.

When further examined the event of destruction or the seal of the synagogue as mentioned above in Indonesia in general or in Central Java in particular, the conflicts that arise can be categorized into three categories with the issues that accompany them. First, cross-flow conflicts within one religion is seen from the many victims who fell from the syi'ah and ahmadiyah including their places of worship; second, interreligious conflicts, in the form of vandalism or rejection of the establishment of places of worship, are seen in the number of churches or mosques that are victims of destruction; and thirdly, inter-faith conflicts and local beliefs,[4] as seen in Central Java regarding the refusal of studio establishments for believers.

The government has actually anticipated the conflict between religious communities, especially the destruction of places of worship by issuing regulations for a long time, namely with the release of Joint Decree (Surat Keputusan Bersama (SKB)) in 1969. However, Joint Decree (SKB) No. $1 / \mathrm{Ber} / \mathrm{MDN}-\mathrm{MAG} / 1969$ is considered too 
discriminatory and does not specify the rules on the establishment of the synagogue, therefore, the Government issued Joint Ministery Regulations (Peraturan Menteri Bersama (PMB)) between Ministry of Religious Affairs and the Ministry of Home Affairs Number No. 9 and 8 of 2006. Ali Fauzi et al (2011: 13) noted since 1969-2006 there were more than 1000 cases of conflicts in the construction of houses of worship mainly related to the establishment of the church. PMB No. 9 and 8 of 2006 set out three things, namely: the fostering of religious harmony through the establishment of Forum Kerukunan Umat Beragama, the procedures for the construction of houses of worship, and the settlement in case of conflict (Noorbani, 2015: 10)

Human Rights Watch (2013: 50) in its studies found that PMB is effectively used by militant groups to block the construction of houses of worship. The group argued that their actions were blocking the construction or closing houses of worship justified because the minority builders who built the houses were ineligible, accusing them of using false data or signals, or the reason that the construction of a synagogue would disturb the peace and harmony of religious communities in the region. Nevertheless, PMB is not always the reason behind the conflict. As a result of the study by Asry (2014: 52-64; bdgk Dachlan, 2015: 69-81; Ahmad, 2013: 335-364) in North Tapanuli, it was found another fact that although the various requirements in PMB have been met by Al-Munawwar, Sarulla, the local community is not pleased that the mosque was founded on the grounds of "inappropriate and unworthy". This excuse is frivolous and has a nuance of dislike from the local majority religious group (Noorbani, 2015: 11-12)

The study of the substance of the law of PMB conducted by Asroni (2012: 84, Khalikin, 2010) indicates that the existence of $\mathrm{PMB}$, in reality, is often a source of conflicts in the construction of houses of worship, because this regulation is full of potential discrimination that is easily utilized by radical religious groups to suppress freedom to build houses of worship. The study of the effectiveness of the Article 14 of the PMB concludes that the substance of law on the implementation of the Article 14 is less effective due to lack of understanding of the community as well as implementers at the local government level, inconsistency of government apparatus in implementing the article, and the absence of sanctions for violators of this rule.

Related to the second issue (protection for the followers of beliefs), it can be seen in the following explanation. Based on data from Komnas HAM 2015 , the number of victims of KBB rights violation from several followers of belief was 7 cases. Under the report, Komnas HAM recorded that there was $\mathrm{KBB}$ rights violation done by state apparatus to the followers of Aji Saka in Rancagong Village, Legok Sub-district, Tangerang Regency, Banten. They believed that Aji Saka followers have conducted blasphemy; even though Aji Saka is not a religion, but a belief. Since Aji Saka is not a religion, people cannot say that it blemishes certain religion. In addition, there is also report from Administrators of Sapta Dharma Unity Center (Pengurus Pusat Persatuan Warga Sapta Dharma) on combustion of small temple/worship house owned by Sapta Dharma people on November $10^{\text {th }} 2015$ in Blando, Plawangan Village, Kragan Subdistrict, Rembang. Setara Institute (2015) noted that there are 2 cases of $\mathrm{KBB}$ rights violation to followers of certain beliefs (Halili, 2016).

Pakem Central Java Province in October 2012 has released the existence of several groups of belief which used to be 396 beliefs but now there were only 336 of them. Around 60 beliefs are gone, dead or inactive. This number does define the real condition since there are many beliefs existed but they do not register themselves with the government. To them, registration is not important but the implementation of teachings from the ancestors in life is what matters (eLSA, 2012; Afandi, 2009; Soedjono, 1996).

Several events which include in discrimination to certain beliefs in Central Java (eLSA, 2012-2014) are explained in the following: demolition of studio of Ngesti Kasampunan belief in Candi Garon Village, Sumowono Sub-district, Semarang Regency which is guarded strictly by sector police officers and Sumowono military rayon command (koramil) was seen by people and public figures; rejections in establishing studio for Sapto Darmo belief are in Blando, Plawangan Village, Kragan sub-district, Rembang Regency. People are worried about the existence of those beliefs including their rituals: apostasy and dismissal of Abas Sheh Maulana Malik Ibrahim belief in Danurejo Village, Kedu Subdistrict, Temanggung; adjudication to Andreas Guntur Wisnu Sarsono, the leader of Amanat Keagungan Illahi belief group which is accused of blasphemy; restriction of religious education is in line with belief uphold by the followers of Sedulur Sikep in Kudus Regency; rejection of funeral for the followers of Sapto Darmo belief in Siandong Village, Larangan Sub-district, Brebes Regency, which then passed away in local public cemetery; similar case also happened in Krangan sub-district, Temanggung Regency to the followers of Mardhi Santosaning Budhi (MSB) belief.

Reflecting on the case of adherents above, it is clear that there is state's involvement in the discrimination. How the state through its agents significantly commits acts of discrimination without any accountability at all. Suffering arising from the Adherents as a result of discrimination of other religions and the state cannot heal only with an announcement or patient manner. In fact (as is the case in Brebes), the state can be controlled by a handful of people. Hence, pledges to protect are only a myth.

When referring to the provision in the regulations concerning about the protection of victims and witnesses, then the only protection given to victims where this case has been entered in the criminal justice system. Whereas in some cases mentioned above, none of that goes to trial, and how citizens are protected. Therefore, it is rather difficult to hold the 
country if the rules are in such ways. Regulations on the protection of victims indeed feel awkward when confronted with cases of discrimination against adherents (and also other religious conflicts). Irregularities include two things: first, the protection of victims is given during the stage of criminal proceedings in the courts (Article 2 and Article 8, paragraph (1)), which aims to provide a sense of security to the process (Article 4); second, the victims who obtain medical assistance and psychosocial rehabilitation are victims of violations of human rights by weight, victims of terrorism, victims of the crime of trafficking in persons, victims of the crime of torture, victims of criminal acts of sexual violence, and victims of severe abuse (Article $6)$.

In connection with the first view, victims case which is not included in criminal justice will not get the protection as seen clearly in the case above. Then on the second issue, the question is whether victims of discrimination by the state or other religion believer get the medical assistance and psycho-social rehabilitation? Are victims of discrimination included in one or more victim from various types of offenses specified in the Article 8? The criterion that comes close is the crime of torture victims, but whether the victim was tortured? Explanation of the article also does not provide clarity at all. So what if the victim is not included in the criteria of the Article 8 , will they still get the grant?

From the cases described above the state did not provide medical assistance or psycho-social rehabilitation at all because the victims did not suffer physically. There are two actions taken by the victims who did not receive protection from the state, namely: first, they cannot do anything on his fate (as in the case of the Ngesti Kasampurnan adherents in Semarang; Sapto Darmo in Rembang; Abas Sheh Maulana Malik Ibrahi in Temanggung; and Andreas Gunturdi Wisnu Sarsono, the leader of Kelompok Kepercayaan Amanat Keagungan Illahi in Klaten); second, to take the fight to find own solutions to problems (such as the right to education for adherents of Sedulur Sikep in Kudus, followers of Sapto Darmo adherents in Brebes, and adherents of adherents Mardhi Santosaning Budhi in Temanggung).

Associated with the third issue (teachings, sects, in one religion and hate speech), there are still events that show lack of respect for differences. Competition and mutual blame between salafi and wahabi, sunni and shia, Islam and ahmadiyan are still ongoing. The release of MUI's fatwa on the haram of pluralism adds to the list of new issues experienced by religious people, especially those with many courses or sects (Islam). Hate speech is also one of the factors that cause this country often in the uncertain conditions in religious life. Postings that insult religion, prophets, clerics, religious leaders, can easily be found on the internet. The power of mass media and electronics is able to divide the nation.

The word of "hate speech" often translated as "hate speech". There are two terms that are often used in the international law of human rights, namely "incitement" and "hate speech". United Nation Human Rights Committee more often uses the term incitement. In practice, there is indeed a difference between the expert and the country's legal system, there is more emphasis word itself, where the consideration of the impact on the humanitarian and human existence, and some are seeing the impact on others who called for the of hate speech (Anam and Hafiz, 2015: 345; Raharjo, 2016).

The differences between incitement and hate speech lie in the intention of a speech that is intended to cause a certain impact, either directly (actual) or indirectly (a stop on the intention). If the speech delivered in the fervent and excited, it turned out to inspire audience to commit violence or hurt another person or group, and then in that position also an incitement is successfully done. However, David O. Brink affirms that there many statements or speech that are discriminatory but are not included in the category of hate speech. This can be illustrated by the bias and evil stereotypes, but not to the degree of stigmatization, degrading, very hurt or injure. Hate speech, as Brink stated, worse than a discriminatory statement. It uses the traditional nickname or symbol to harassing someone because of his attachment to a particular group and as an expression of insult to the target in order to affect psychologically (Anam and Hafiz, 2015: 345-346; Raharjo, 2016).

Point of contact of hate speech within the framework of the human rights is at two discourses of rights, namely: a) freedom of religion or belief; and b) freedom of expression and opinion, c) the protection of race and ethnicity. Through the International Covenant on Civil-Political Rights and a number of other international documents, the global community has agreed on the boundaries of both rights, so that restriction on a right (expression and speech) to protect certain rights (freedom of religion) is not supposed to be seen within the framework of a dichotomous (Durham and Scharff, 2010: 202; Raharjo, 2016).

Right of religion and belief is a fundamental right protected, even including one of the rights that cannot be restricted in any situation (non-derogable rights) (Nowak, 2004: 147) as regulated in the Article 28 paragraph (1) of the 1945 Constitution and the Article 4 of the International Covenant on Civil and Political Rights (ICCPR). It was different with the rights of expression and speech which are not absolute and can be limited. Restriction of the right of expression and opinion based on the opinion of the UN Human Rights Committee can be done to respect and protect the reputation of another person, someone who is individual as part or member of a community, such as religious or ethnic. The Article 20 paragraph (2) International Covenant on Civil and Political Rights (ICC-PR) affirms that all advocacy of hatred on the basis of nationality, racial or religion constitutes incitement to discrimination, hostility or violence shall be prohibited by law. This article asserts that the state should prohibit all forms of hatred boost in domestic law, including incitement to discrimination, have no impact on violence based on 
national identity, race, or religion (Anam and Hafiz, 2015: 345; Raharjo, 2016).

Related to this hate speech, Indonesian Criminal Codes are generally set in Article 310 paragraph (1), paragraph (2), Article 311 paragraph (1) Criminal Code. However, those articles are more related to personal attacks and are individuals, whereas in hate speech, religion offenses in particular attacks aimed at the whole people of one religion, so that the number of victims was mass. Besides, these chapters are not related to the use of internet media for the purpose of the crime, although they can be enforced with the interpretation, they will feel not the same. Regulation related to the speech of hatred by using the existing internet is based on Article 28 paragraph (2) Law No. 11 of 2008 on Information and Electronic Transactions. This article specifies any person intentionally and without the right to disseminate information intended to cause hatred or hostility individual and/or a particular group of people based on ethnicity, religion, race, and intergroup (SARA). The criminal provisions of this article contained in Article 45 paragraph (2), which specifies that any person who meets the elements referred to Article 28 paragraph (1) or paragraph (2) shall be punished with imprisonment of 6 (six) years and/or fine of not more Rp1,000,000,000.00 (one billion rupiahs). Although the rules are clear, there are still many unresolved cases. This is where the law appears the state does not work optimally (Raharjo, 2016).

Based on the facts mentioned above, it appears that the harmony between intra and inter-religious people in Indonesia is still a big problem. Tolerance and dialogue that is often campaigned, seems not trace the trigger factor and drive factor (Turchetti, 1991; Yovel, 1991; Williams, 1996; Benbaji and Heyd, 1996; Galeoti, 2001; McClure, 1990; Forst, 2001; Smith, 1987; 1990). The state seems unable to resolve this easily, either because of the state's inability or the negligence of its apparatus in fulfilling its obligations so that it is no more than a myth (Fidiyani and Baidhowi, 2015: 278-279).

Myths arise when what is believed to be a truth is, in reality, met with unrighteousness. From what is aspired to the reality presented, there is a gap or a fairly wide difference. The state's protection and guarantee of freedom of religion and belief is a myth, compared to the reality presented to us by the events of that offense. The practice is not to eradicate myths or not to present myths, but to reinforce the old myth of freedom of religion and belief.

\section{CONCLUSION}

The best mythical creator is the state; this is indicated by the sweet promises made by the state through the constitution and its laws and regulations. This sweet promise captivates everyone. Unfortunately, the promises are often not kept and even tended to be a myth that is proven to be true. The guarantee and protection of freedom of religion and belief is the sweet promise it offers. The practice of guarantee and protection is still far from the reality, there are still many violations of freedom of religion and belief everywhere. These violations confirm that freedom of religion and belief is a myth.

\section{ACKNOWLEDGMENTS}

The writer would like to express gratitude to everyone who has helped the writer during the fulfillment of the research and this paper. First and foremost, the writer expresses thank you to Director General, Directorate of Research and Community Service, Directorate General for Research and Development, Ministry of Research, Technology and Higher Education who has funded the Research in National Strategic Research Scheme; Chairman of Research and Service Institute of Universitas Negeri Semarang, Dean of Law Faculty, Universitas Negeri Semarang and his staff who have given the writer moral support and handle research permission; as well as some students who have assisted in searching, collecting and processing research data.

\section{REFERENCES}

[1] Some of these prominent incidents are: a) Restriction to Build Batuplat Mosque in Kupang - NTT; b) Restriction to Build Mushalla As Syafiiyah in Denpasar; c) Dismissal of 19 churches activities in Aceh Singkil; d) Sealing of 7 churches in Banda Aceh; e) Discontinuation to Build Churches in Bandung; and f) Sealing of 7 churches in Cianjur.

[2] Setara Institute (2016) recorded that there are severa prominent cases in 2015. Several prominent cases meant are: a) Sealing of Ahmadiah Mosques in Jawa Barat, namely: (1) Al Furqon Mosques JAI in Kersamaju, Kersamaju Village, Cigalontang, Tasikmalaya. Sealed since March 31 ${ }^{\text {st }} 2015$ until now; (2) Istiqomah JAI Mosque in Banjar, sealed since September $29^{\text {th }} 2011$ until now; (3) JAI Mosque in Tolenjeng, Tasikmalaya Regency, sealed since 2003 until now; (4) Basyarat JAI Mosque in Sukaraja, sealed since August $31^{\text {st }} 2007$ until now; (5) Al Mahmud JAI Mosque in Singaparna, Tasikmalaya, sealed since 2013 until now; (6) JAI Mosque in Ngampang, Cilawu, Garut Regency, since September $26^{\text {th }} 2014$ until now. b) Tolikara Case in Manokwari, Papua; c) Declaration Anti-Syi'ah in various places; d) Sealing case of 3 churches in Bekasi; e) Attacking case of church in Aceh Singkil.

[3] According to the result of research from eLSA (2012-2014), they display a series of events, namely: discontinuation of Mennonite Church establishment in Tanah Java (GITJ) Dermolo Village, Kembang Subdistrict, Jepara Regency; the problem of Iman Meitreya monastery establishment in Seruni Street RT. 03 RW. 04, Sidorejo Lor, Salatiga; demolition of buildings owned by religious sect of Ngesthi Kasampurnan (NK) in Sumowono, Semarang; rejec-tion of small Sapto Darmo small temple establish-ment in Blando, Plawangan Villange, Karagan Subdistrictm Rembang Regency; shutting down Al-Kautsar mosque owned by Ahmadiah congregation in Purworejo village, Ringinarum Subdistric, Kendal Regency by Civil Service Police Unit (Satpol PP); shutting down Majelis Tafsir Quran Building in Grobongan by Civil Service Police Unit (Satpol PP) Grobongan District Government with the reason, there is no Building Permit (IMB); discontinuation of building house owned by Romo Gregorius Utomo which allegedly will be used as Church or worship house in Rejosos Villahe, Jogonalan Subdistrict, Klaten; destruction and shuttinh down of Santri Luwung Islamic Boarding School (Ponpes) in Bedo-wo, Jetak Village, Sidoharjo, Sragen; vandalism of temple in Dukuh Giriloka, Girimargo Villahe, Miri 
Subdistric, Sragen Regency; and establishment of church for Gereja Kristen Jawa (GKJ) Mejasem congregation in Tegal which faces a lot of obstacle. several of those matter has been resolved in 2016; nevertheless, there are some which has not been solved yet, for examole Inijili Church establishment in Tanah Jawa (GITJ) in Jepara as well as the newest issue which is vandalism to mosque owned by ahmadiyah congregation in Kendal.

[4] Belief is not a religion. Belief is defined as something that fills a place in human life that is on par with something that conferred by god or gods of the grip of this particular religious beliefs. Look this meaning in The Wahid Institute (2014). Referring to this definition, there could be someone who has a certain belief even though he did not belong to one religion.

[5] Ahmad Nur. (2013). Pesan Dakwah dalam Penyelesaian Konflik Pembangunan Rumah Ibadah (Kasus Pembangunan Rumah Ibadah antara Islam dan Kristen Desa Payaman). Jurnal Fikrah, 1(2), 335-364.

[6] Afandi, Fachrizal. (2009). PAKEM: Salah Satu Upaya Negara dalam Melindungi Agama. Jurnal Al-Qanun, 12 (2).

[7] Ali-Fauzi, Ihsan, et.al. (2011). Kontroversi Gereja di Jakarta. Yogyakarta: CRCS Universitas Gajah Mada.

[8] Anam, M. Choirul dan Muhammad Hafiz. (2015). Surat Edaran kapolri tentang Penanganan Ujarn Kebencian (Hate Speech) dalam Kerangka Hak Asasi Manusia. Jurnal Keamanan Nasional, 1 (3)

[9] Asroni, Ahmad. (2012). Menyegel "Rumah Tuhan": Menakar Kadar Kemaslahatan Peraturan Bersama Menteri Agama dan Menteri Dalam Negeri No. 9/2006 dan No. 8/2006," dalam Mereduksi Konflik Pendirian Rumah Ibadat di Indonesia. Jurnal Religi, VIII (1), 21-27.

[10] Benbaji, Hagit and David Heyd. (2001). The Charitable Perspective: Forgiveness and Toleration as Supererogatory. Canadian Journal of Philosophy 31: 567-86.

11] Blake, Garth. (2007). Promoting Religious Tolerance in a Multifaith Society: Religious Vilification Legislation in Australia and the UK. 81 Australian Law Journal 386.

[12] Asry, Yusuf. (2014). Miskomunikasi dan Robohnya Sendi Harmoni Antar Kristen-Islam dalam Pembangunan Masjid Al-Munawar Narhornop Marsada, Kabupaten Tapanuli Utara. Jurnal Harmoni, 13(1), 52-64.

[13] Carmella, Angela C. (1991). Houses of Worship and Religion Liberty: Constitutional Limits to Landmark Preservation and Architectural Review. 36 Villanova Law Review 401.

[14] Cumper, Peter. (1998). School Worship: Praying for Guidance. 1 European Human Rights Law Review 45.

[15] Dachlan, Muh. (2015). Dinamika Pendirian Gereja Kristen Songka dan Gereja Toraja Jemaat Marannu di Kota Palopo. Jurnal SmaRT, 01(01), 69-81.

[16] Dickson, Brice. (1995). The United Nations and Freedom of Religion. 44 International and Comparative Law Quarterly 327.

[17] du Plessis, Lourens. (2001). Freedom of or Freedom from Religion: An Overview of Issues Pertinent to the Constitutional Protection of Religious Rights and Freedom in "the New South Africa. Brigham Young University Law Review 439.

[18] Durham, W. Cole and Brett G. Scharffs. (2010). Law and Religion: National, International, and Comparative Perspective, New York: Aspen Publisher.

[19] eLSA. (2012). Laporan Tahunan Kebebasan Beragama dan Berkeyakinan di Jawa Tengah 2012. Semarang: ELSA.

[20] eLSA. (2013). Laporan Tahunan Kebebasan Beragama dan Berkeyakinan di Jawa Tengah 2013. Semarang: ELSA.

[21] eLSA. (2014). Laporan Tahunan Kebebasan Beragama dan Berkeyakinan di Jawa Tengah 2014. Semarang: ELSA

[22] Ferrari, Silvio. (2004). Individual Religious Freedom and National Security in Europe after September 11. Brigham Young Law Review 357

[23] Fidiyani, Rini and Baidhowi. (2015). Legal Development Based on Local Wisdom as the Basis of a Setting for Religious Life in Central Java. Jurnal Dinamika Hukum, 15(3). 278-286

[24] Fidiyani, Rini. (2016). Liability of State toward Discriminative Act to Adherent. In Marc Groenhuijsen (Eds), Proceedings of International Conference on Victimology and Victim Assistance in Indonesia (pp. 270-
290). Purwokerto: Faculty of Law Jenderal Soedirman University.

[25] Fidiyani, Rini. (2016). Bekerjanya Hukum Negara dalam Penyelesaian Pelanggaran Kebebasan Beragama/Berkeyakinan, Paper presented at Seminar Nasional "Pembangunan Hukum Nasional di Era Ekonomi Masyarakat ASEAN, Surabaya: Faculty of Law UNESA;

[26] Fidiyani, Rini. (2016). Dinamika Pembangunan Rumah Ibadah Bagi Warga Minoritas Di Jawa Tengah. Paper presented at Seminar Nasional Multidisiplin Ilmu and Call for Papers UNISBANK Ke-3, Semarang: UNSIBANK;

[27] Forst, Rainer. (2001). Tolerance as a Virtue of Justice. Philosophical Explorations 3, 193-94.

[28] Galeotti, Anna E. (2001). Toleration as a Moral Virtue. Res Publica 273-92.

[29] Halili (2016). Politik Harapan Minim Pembuktian, Laporan Kondisi Kebebasan Beragama/Berkeyakinan di Indonesia 2015, Jakarta: Pustaka Masyarakat Setara.

[30] Hendropuspito, D. (1983). Sosiologi Agama, Yogyakarta: Kanisius

[31] Human Rights Watch. (2013). Atas Nama Agama: Pelanggaran terhadap Minoritas Agama di Indonesia.

[32] Igadrie, Syarif I. (2002). Konflik Etnis di Ambon dan Sambas: Suatu Tinjauan Sosiologis. Jurnal Antropologi Indonesia, XXXI(58). 34-47.

[33] Junus, Umar. (1981). Mitos dan Komunikasi, Jakarta: Penerbit Sinar Harapan.

[34] Khalikin, Ahsanul. (2010). Pendirian Rumah Ibadah dalam Perspektif PMB No. 9 dan 8 Tahun 2006: Kasus Pencabutan IMB Gereja HKBP Pangkalan Jati Gandul, Kec Limo Kota Depok. Jurnal Harmoni, IX (35), 187-195.

[35] Komnas HAM. (2015). Laporan Akhir Tahun Pelapor Khusus Kebebasan Beragama dan Berkeyakinan Komisi Nasional Hak Asasi Manusia RI, Jakarta: Komnas HAM.

[36] McClure, Kirstie (1990). Difference, Diversity, and the Limits of Toleration. Political Theory 18 (3): 361-91.

[37] McCrudden, Christopher. (2011) 'Multiculturalism, freedom of religion, equality, and the British constitution: The JFS case considered. 9 International Journal of Constitutional Law 200.

[38] Misrawi, Zuhairi. (2010). Al-Qur'an Kitab Toleransi, Tafsi Tematik Islam Rahmatan lil'Alamin, Jakarta: Pustaka Oasis.

[39] Nainggolan, Yosa A. Et.al. (eds). (2009). Pemaksaan Terselubung Hak Atas Kebebasan Beragama dan Berkeyakinan, Jakarta: Komnas HAM

[40] Nevitte, Neil and Christopher Cochrane. (2006). Individualization in America and Europe: Connecting Religious and Moral Values," Comparative Sociology 5(23): 203-31.

[41] Noorbani, M. Agus. (2015). Pendiria Rumah Ibadat di Kota Cirebon Pasca Pemberlakuan Peraturan Bersama Menteri Agama dan Menteri Dalam Negeri Nomor 9 dan 8 Tahun 2006. Harmoni - Jurnal Multikultural dan Multireligius, 14(3). 9-22.

[42] Nowak, Manfred. "Permissible Restriction on Freedom of Religion or Belief", in Tore Lindholm, et.al., ed. (2004). Facilitating Freedom of Religion or Belief: A Deskbook, USA: Martinus Nijhoff Publisher;

[43] Parkinson, Patrick (2007). Religious Vilification, AntiDiscrimination Laws and Religious Minorities in Australia: The Freedom to Be Different. 81 Australian Law Journal 954.

[44] Pelly, Usman. (1999). Akar Kerusuhan Etnik di Indonesia: Suatu Kajian Awal Konflik dan Disintegrasi Nasional di Era Reformasi. Jurnal Antropologi Indonesia, 21(58). 58-70.

[45] Pruit, Dean G dan J.Z. Rubin. (2004). Teori Konflik Sosial. Yogyakarta: Pustaka Pelajar.

[46] Raharjo, Agus (2016). Legal Protection for Victim of Religious Offences on the Internet. In Marc Groenhuijsen (Eds), Proceedings of International Conference on Victimology and Victim Assistance in Indonesia (pp. 270290). Purwokerto: Faculty of Law Jenderal Soedirman University.

[47] Robinson, Kathryn. (2000). Ketegangan Antar Etnis, Orang Bugis dan Masalah 'Penjelasan". Jurnal Antropologi Indonesia, Year XXIV No. 63 (22)

[48] Smith, Steven D. (1987). Skepticism, Tolerance, and Truth in the Theory of Free Expression. Southern California Law Review 60, 685-89. 
[49] Smith, Steven D. (1990). The Restoration of Tolerance. 78 California Law Review 305.

[50] Smith, Steven D. (2002). Believing Persons, Personal Believing: The Neglected Center of the First Amendment. University of Illinois Law Review 1233.

[51] Soedjono C. (1996). Pedoman Tugas-tugas PAKEM, Surabaya: Kejaksaan Tinggi Jawa Timur.

[52] Suparlan, Parsudi. (2000) Mayarakat Majemuk dan Perawatannya". Jurnal Antropologi Indonesia, No. 63 (22).

[53] Suparlan, Parsudi. (2009). Paradigma Naturalistik dalam Penelitian Pendidikan: Pendekatan Kwalitatif dan Penggunaannya. Antropologi Indonesia, 53(21): 91-115.

[54] The Wahid Institute (2014). Laporan Tahunan Kebebasan Beragama/Berkeyakinan dan Intoleransi 2014, "Utang" Warisan Pemerintah Baru, Jakarta: The Wahid Institute.

[55] Thohir, Mudjahirin. (2010). Fundamentalisme Keagamaan dalam Perspektif Kebudayaan. Jurnal Analisa, XVII(02). 165-174.

[56] Turchetti, Mario. (1991). Religious Concord and Political Tolerance in Sixteenth and Seventeenth-Century France Sixteenth Century Journal 22: 15-25.

[57] Williams, Bernard. (1996). Toleration, A Political or Moral Virtue?" Diogenes 44: 36

[58] Yovel, Yirmiyahu. (1998). Tolerance as Grace and as Rightful Recognition. Social Research 65: 897-919. 